\title{
Food habits and endozoochorous seed dispersal by small rodents (Cricetidae and Echimyidae) in a riparian forest in southeastern Brazil
}

\section{Hábitos alimentares e dispersão endozoocórica de sementes por pequenos roedores (Cricetidae and Echimyidae) em uma floresta ripária no sudeste do Brasil}

\author{
Leonardo G. Lessa ${ }^{1}$, Camilla S. Paula ${ }^{1}$, Rafael S. Pessoa ${ }^{1}$ \\ 1 Universidade Federal dos Vales do Jequitinhonha e Mucuri, Departamento de Ciências Biológicas, \\ Programa de Pós-Graduação em Biologia Animal, Diamantina, MG, Brazil \\ Corresponding author: Leonardo G. Lessa (leoglessa@gmail.com)
}

Academic editor: A.M. Leal-Zanchet | Received 19 March 2019| Accepted 30 June 2019| Published 5 November 2019

Citation: Lessa LG, Paula CS, Pessoa RS (2019) Food habits and endozoochorous seed dispersal by small rodents (Cricetidae and Echimyidae) in a riparian forest in southeastern Brazil. Neotropical Biology and Conservation 14(3): 349-359. https://doi.org/10.3897/neotropical.14.e47403

\begin{abstract}
We analyzed the feeding habits and the endozoochoric seed dispersal of six species of Neotropical small rodents in a riparian forest in the Cerrado biome at the central portion of Espinhaço Mountain Range, Brazil. The species presented a miscellaneous diet consuming arthropod, especially Hymenoptera (ants) and Isoptera (termites), fruits of pioneer species and vegetative parts of plants (stems and leaves). The high frequency of arthropods in the diet of all species studied reinforces its importance as a food resource for small Neotropical rodents, especially in environments with a marked seasonality, such as in the Cerrado. The number of intact seeds after gut passage and the higher germinability of the ingested seeds, compared to the control group, indicates that the studied rodents acted mainly as dispersers and not as predators of small seeds ( $\leq 1 \mathrm{~mm}$ ) of pioneer species (Melastomataceae and Rubiaceae).
\end{abstract}




\section{Resumo}

Analisamos os hábitos alimentares e a dispersão endozoocórica de sementes por seis espécies de pequenos roedores neotropicais em uma floresta ripária no bioma Cerrado localizada na porção central da Cadeia do Espinhaço, Brasil. As espécies apresentaram uma dieta diversificada consumindo artrópodes, especialmente Hymenoptera (formigas) e Isoptera (cupins), frutos de espécies pioneiras e partes vegetativas de plantas (caules e folhas). A alta frequência de artrópodes na dieta das espécies estudadas reforça sua importância como recurso alimentar para pequenos roedores neotropicais, especialmente em ambientes com marcada sazonalidade, como no caso do bioma Cerrado. O número de sementes intactas após passagem pelo trato digestório e a alta germinabilidade das sementes ingeridas, em comparação ao grupo controle, indica que os roedores estudados atuam principalmente como dispersores e não como predadores de pequenas sementes $(\leq 1 \mathrm{~mm})$ de espécies pioneiras (Melastomataceae e Rubiaceae).

\section{Keywords}

Cerrado, diet, scarification, Espinhaço Range

\section{Palavras-chave}

Cerrado, dieta, escarificação, Cadeia do Espinhaço

\section{Introduction}

Small rodents are the most diverse group of Neotropical terrestrial mammals (Emmons and Feer 1997; Patton et al. 2015). Knowledge of rodent feeding habits contributes not only to understanding their ecology, but it also allows us to obtain basic information that enables action on population conservation, management and restoration of rodent populations (Sahley et al. 2015). Most of the small Neotropical rodents (Cricetidae and Echimyidae) have been regarded as omnivorous (may be primarily frugivorous, herbivorous or granivorous), consuming fruits, seeds, and vegetative plant parts (stems, leaves or roots) (see Grenha et al. 2010; Paglia et al. 2012; Sahley et al. 2015). Nevertheless, recent studies have revealed a high consumption of arthropods by several species (Lessa and Costa 2009; Pinotti et al. 2011; Polop et al. 2014; Sahley et al. 2015; Galetti et al. 2016).

Because of their feeding habits and abundance in Neotropical habitats, rodents can affect seed dispersal and the survival of several plant species, directly influencing their spatial distribution pattern (Brewer and Rejmanék 1999; Lessa and Costa 2009; Grenha et al. 2010; Dittel et al. 2015). Their potential as seed dispersers is mainly related to their habit of storing seeds for later consumption (synzoochory), i.e. the transport of seeds outside their bodies, such as when a rodent removes a fruit/seed in his mouth to another place (Horn et. al. 2008 Brewer and Rejmanék 1999; Almeida and Galetti 2007; Haugaasen et al. 2010). These animals can, however, also act as endozoochorous dispersers, consuming and dispersing viable seeds after gut passage (Horn et al. 2008 Lessa and Costa 2009; Dittel et al. 2015; Sahley et al. 2016). In this context, rodents are particularly important and can act as dispersing agents, transporting seeds from one location to another (Horn et al. 2008 
Carvajal and Adler 2008; Lessa and Costa 2009; Dittel et al. 2015; Sahley et al. 2016), or also as mortality agents, damaging the seeds consumed (Briani and Junior 2007; Carvajal and Adler 2008; David et al. 2015).

Endozoochorous seed dispersal results from a mutualistic interaction between plants and the animals that feed on ripe and nutritious fleshy fruits containing one or several seeds (Howe and Smallwood 1982; Lessa et al. 2013). Therefore, the role of small mammals as potential seed dispersers is usually related to the consumption of a wide variety of fruits and the presence of intact seeds in their feces, with generally increased germinability (Magnusson and Sanaiotti 1987; Vieira et al. 2006; Lessa and Costa 2009; Lessa et al. 2013). However, the process of gut scarification of the seed coat by passage through the digestive tract of small mammals (rodents and marsupials) does not always have positive effects on the germinability of the ingested seeds (see Traveset 1998; Lessa and Costa 2009; Cantor et al. 2010; Lessa et al. 2013; Sahley et al. 2016).

Small rodents can achieve higher density and higher biomass than larger species (Emmons and Feer 1997), however, their habits associated with their small size and efficient masticatory apparatus, equipped with chisel incisors and molariform teeth, are factors that may hinder studies on the food ecology of this group (Vieira et al. 2003; Lessa and Costa 2009). Another important aspect to consider when assessing the diet of a species is related to the availability of food resources (Pinotti et al. 2011). Seasonal environments, such as the Cerrado biome, can determine the diet of the species, since the availability of resources, especially arthropods and fruits, may vary during the year (Pinotti et al. 2011; Camargo et al. 2014; Melo et al. 2019). Furthermore, the degree of frugivory and the relative importance of the food items that make up their diet remain unknown for most species (Lessa and Costa 2009).

The present study described the diet, analyzed seasonal variations in the diet composition and examined the effects of gut passage on seed germination of fruit consumed by six species of small rodents collected in a riparian forest in the Cerrado of southeastern Brazil: Cerradomys subflavus (Wagner, 1842), Rhipidomys mastacalis (Lund, 1840), Oligoryzomys nigripes (Olfers, 1818), Nectomys squamipes (Brants, 1827), Necromys lasiurus (Lund, 1841) and Thrichomys apereoides (Lund, 1839).

\section{Material and methods}

\section{Study site}

We conducted the study in a riparian forest in Rio Preto State Park (RPSP; $18^{\circ} 09^{\prime}$ S, $\left.43^{\circ} 23^{\prime} \mathrm{W}\right)$, a fragment (12,000 ha) of the Cerrado biome located in the southern portion of the Espinhaço Mountain Range in the state of Minas Gerais, Brazil. The vegetation at the RPSP consists of Cerrado, which is a tropical savanna formation comprising different vegetation formation physiognomies (Oliveira-Filho and Ratter 2002), which includes: campos rupestres (dry rock grasslands), Cerrado (stricto sensu), cerradão (closed savanna) and riparian forests along the banks of the Rio Preto River. The climate is type $C w b$, according to the Köppen classification, with 
mild, humid summers (October to April) and cool and dry winters (June to August). The average annual rainfall varies from 223 to $1550 \mathrm{~mm}$ and the average annual temperature ranges from $17^{\circ} \mathrm{C}$ to $19^{\circ} \mathrm{C}$ (Neves et al. 2005).

We also captured the following small mammal species in the same study site, the rodents Thalpomys lasiotis Thomas, 1916; Cerradomys scotti (Langguth \& Bonviccino, 2002); and the didelphid marsupial's Gracilinanus agilis (Burmeister, 1854); Marmosops incanus (Lund, 1840); Metachirus nudicaudatus (Desmarest, 1817); Monodelphis domestica (Wagner, 1842) and Didelphis albiventris Lund, 1840 (see Lessa and Paula 2014).

\section{Sampling of rodents}

We captured rodents monthly from November 2009 to October 2011, through the capture-mark-recapture method. We used 96 galvanized wire traps $(300 \times 160 \times 160 \mathrm{~mm})$ arranged in four $180 \mathrm{~m}$ parallel transects, $50 \mathrm{~m}$ apart. In each transect, we installed 12 capture stations, spaced apart by $15 \mathrm{~m}$. As bait we used fruits (orange pieces), cotton balls soaked in Scotch emulsion and bacon bits. Captured animals were identified, marked with numbered ear tags (Zootech) and released at the same location.

\section{Fecal analyzes}

We collected feces directly from each specimen during manipulation or from inside the trap and stored samples in paper envelopes preserved at $-10{ }^{\circ} \mathrm{C}$ to avoid fungi infestation. One fecal sample was considered as being all feces produced by a single animal in one night. In the laboratory, we examined samples under a stereoscopic microscope and identified food items to the lowest taxonomic level.

We used the relative frequency of occurrence (FO) expressed as the number of samples where an item was found $(n)$ divided by the total number of samples and multiplied by 100, to determine the contribution of each item to the diet of rodents (Korschgen 1987). We excluded samples from recaptures of the same individuals, avoiding pseudo-replicates (Hurlbert 1984). We compared the diet for the four species with seven or more fecal samples using $\mathrm{G}$ test (Zar 2010) to compare the FO of animal items (arthropods) versus vegetal items (seeds and plant fragments) among species.

\section{Germination tests}

We separated the seeds found in the samples (before storing the feces at $-10^{\circ} \mathrm{C}$ ) and set them to germinate under natural lighting conditions in Petri dishes containing a double layer of moistened filter paper. As a control group, we manually removed the seeds from mature fruits of the same species consumed and set them to germinate in similar conditions. Dishes were moistened regularly with distilled water and monitored daily for seed germination, defined as when protrusion of the hypocotylroot axis was detected. Seedling emergence was recorded weekly for a total of 24 months. We tested the influence of gut passage on germination speed by means of a 
Komolgov-Sminirnov test on the comparison of the cumulative percentage of seed germination between ingested seeds and control group (Zar 2010). We used the chisquare to test for differences in germinability between the control group and seeds found in the samples, (Zar 2010). We used the term germinability to indicate the final proportion of germinated seeds (Ranal and Santana 2006). For all analyses, we used a significance level at 5\% employing the statistical program BioEstat 5.0.

\section{Results}

\section{Diet composition}

Totalizing 9,216 trap-nights, we obtained 69 fecal samples belonging to five Cricetidae species: C. subflavus $(\mathrm{n}=32)$, R. mastacalis $(\mathrm{n}=17)$, O. nigripes $(\mathrm{n}=8), N$. squamipes $(\mathrm{n}=7)$, N. lasiurus $(\mathrm{n}=2)$ and one Echimyidae: T. apereoides $(\mathrm{n}=3)$ (Table 1). We found arthropods in all fecal samples (100\%), and the most frequent orders were Hymenoptera (ants) and Isoptera (termites) (Table 1). We found six different morphotypes of seeds and other plant parts (leaves, stems, and roots), belonging to four botanical families: Melastomataceae (Clidemia urceolata and Miconia holosericeae), Myrtaceae (Myrcia sp.), Cactaceae (unidentified), and Rubiaceae (Psychotria capitata and Psychotria sp.). All species (except $N$. lasiurus) consumed vegetative plant parts (leaves, stems, and roots) in different proportions (Table 1).

We observed a significant difference in the consumption of arthropods items ( $G$ $=288.5, \mathrm{df}=27, P<0.01)$ and plant items (seeds and plant parts) $(\mathrm{G}=63.1, \mathrm{df}=18$, $P<0.01$ ) among the four species compared (C. subflavus, $R$. mastacalis, $O$. nigripes and N. squamipes).

We found no differences for diets between dry and rainy seasons, for any of the food items categories (arthropods: $\chi^{2}=0.05, \mathrm{df}=1, P=0.869$; seeds: $\chi^{2}=1.61, \mathrm{df}=$ $1, P=0.267$ and plant fragments: $\chi^{2}=2.17, \mathrm{df}=1, P=0.140$ ).

Most intact seeds found in samples (92.7\%) were small (size $\leq 1 \mathrm{~mm}$ long), and the proportion of intact seeds was higher than that of damaged seeds $(\mathrm{G}=22.0$, $\mathrm{df}$ $=5, P<0.01)($ Table 2$)$.

\section{Germination}

We conducted germination experiments only with intact seeds of pioneer species of Melastomataceae and Rubiaceae. In comparison with the control group, germination speed of the gut-passed seeds was significantly higher $(\mathrm{p}<0.01)$. Most intact Melastomataceae seeds showed significantly higher germinability compared with the control group in: $R$. mastacalis (C. urceolata: $\chi^{2}=40.44, \mathrm{df}=1, P<0.01$; and $M$. holosericea: $\chi^{2}=35.31, \mathrm{df}=1, P<0.01$ ); $N$. squamipes (C. urceolata: $\chi^{2}=30.55$, df $=1, P<0.01$ ) and $N$. lasiurus (C. urceolata: $\left.\chi^{2}=22.75, \mathrm{df}=1, P<0.01\right)$. Rubiaceae seeds found in $C$. subflavus samples did not show higher germinability than that of the control group (Psychotria capitata: $\chi^{2}=7.14, \mathrm{df}=1, P=0.075$; and Psychotria sp.: $\left.\chi^{2}=1.42, \mathrm{df}=1, P=0.232\right)($ Table 3$)$. 
Table 1. Relative frequency of occurrence (\%) of food items found in the scats of six rodents' species. Cs = Cerradomys subflavus; $\mathrm{Rm}=$ Rhipidomys mastacalis; On = Oligoryzomys nigripes; $\mathrm{Ns}=$ Nectomys squamipes; $\mathrm{Ta}=$ Thrichomys apereoides and; $\mathrm{Nl}=$ Necromys lasiurus; $n=$ total number of scats analyzed.

\begin{tabular}{|c|c|c|c|c|c|c|}
\hline Food itens & Cs $(n=32)$ & $\operatorname{Rm}(n=17)$ & On $(n=8)$ & Ns $(n=7)$ & $\mathrm{Ta}(n=3)$ & $\mathrm{Nl}(n=2)$ \\
\hline Arthropoda (total) & 100 & 100 & 100 & 100 & 100 & 100 \\
\hline Aracnidae & 3.1 & - & - & 28.6 & - & - \\
\hline Blattodea & 9.3 & 5.9 & 25 & 14.3 & - & - \\
\hline Coleoptera & 9.3 & - & - & 14.3 & - & - \\
\hline Dermaptera & - & - & 12.5 & - & - & - \\
\hline Diptera & 3.1 & - & - & 14.3 & - & - \\
\hline Diplopoda & 3.1 & - & - & - & - & - \\
\hline Hymenoptera & 43.7 & 17.6 & 12.5 & 57.1 & 100 & 50 \\
\hline Isoptera & 43.7 & 23.5 & 37.5 & 42.8 & 100 & 50 \\
\hline Larva & - & - & 12.5 & - & - & - \\
\hline Orthoptera & 3.1 & - & 12.5 & - & - & - \\
\hline Unidentified Arthropoda & 81.2 & 70.6 & 62.5 & 57.1 & 66.7 & 50 \\
\hline Seeds (total) & 21.9 & 17.6 & - & 14.3 & - & 100 \\
\hline \multicolumn{7}{|l|}{ MELASTOMATACEAE } \\
\hline Clidemia urceolata & 6.2 & 5.9 & - & 14.2 & - & 50 \\
\hline Miconia holosericea & 6.2 & 5.9 & - & 14.2 & - & - \\
\hline \multicolumn{7}{|l|}{ MYRTACEAE } \\
\hline Myrcia sp. & 3.1 & - & - & - & - & - \\
\hline CACTACEAE & 3.1 & - & - & - & - & - \\
\hline \multicolumn{7}{|l|}{ RUBIACEAE } \\
\hline Psychotria capitata & - & 5.9 & - & - & - & - \\
\hline Psychotria sp. & 3.1 & - & - & - & - & 100 \\
\hline Plant parts (total) & 21.9 & 23.5 & 12.5 & 14.2 & 66.6 & - \\
\hline
\end{tabular}

Table 2. Total number $(n)$ and percentage of samples (\%) containing intact and damaged seeds.

\begin{tabular}{lccc}
\hline \multicolumn{1}{c}{ Family/Species } & Scats $(\boldsymbol{n})$ & Intact seeds (\%) & Damaged seeds (\%) \\
\hline Cricetidae & & & \\
Cerradomys subflavus & 32 & 89.5 & 10.5 \\
Rhipidomys mastacalis & 17 & 88.5 & 11.5 \\
Oligoryzomys nigripes & 8 & 0 & 0 \\
Nectomys squamipes & 7 & 100 & 0 \\
Necromys lasiurus & 2 & 97.3 & 2.7 \\
Echimyidae & & 0 & 0 \\
Thrichomys apereoides & 3 & &
\end{tabular}

Table 3. Results of the germination tests in the Control Group (CG) and seeds collected from the feces. Results expressed as total number of seeds tested (number of seeds germinated in $\%$ ); ${ }^{*} \mathrm{p}<0.05$.

\begin{tabular}{lcccccc}
\hline \multicolumn{1}{c}{ Family/Species } & $\begin{array}{c}\text { Seed size } \\
(\mathbf{m m})\end{array}$ & CG & $\begin{array}{c}\text { Rhipidomys } \\
\text { mastacalis }\end{array}$ & $\begin{array}{c}\text { Cerradomys } \\
\text { subflavus }\end{array}$ & $\begin{array}{c}\text { Necromys } \\
\text { lasiurus }\end{array}$ & $\begin{array}{c}\text { Nectomys } \\
\text { squamipes }\end{array}$ \\
\hline Melastomataceae & & - & - & - & - & - \\
Clidemia urceolata DC. & 1 & $45(22 \%)$ & $19(89 \%)^{*}$ & - & $16(67 \%)^{*}$ & $14(77 \%)^{*}$ \\
Miconia holosericea (L.) DC. & 1 & $45(26 \%)$ & $10(90 \%)^{*}$ & - & - & - \\
Rubiaceae & & - & - & - & - & - \\
Psychotria sp. & 0.8 & $20(30 \%)$ & - & $10(40 \%)$ & - & - \\
Psychotria capitata Ruiz and Pav. & 2 & $20(18 \%)$ & - & $13(38 \%)$ & - & - \\
\hline
\end{tabular}




\section{Discussion}

The six rodent species recognized as herbivorous or frugivorous (see Paglia et al. 2012) presented a miscellaneous diet, consuming animal preys (arthropods), and plant items (fruits, leaves, stems, and flowers) in different proportions. A similar pattern was also reported for Cricetidae (Pinotti et al. 2011; Sahley et al. 2015) and Echimyidae rodents (Lessa and Costa 2009; Dittel et al. 2015). However, it is important to highlight the high frequency of arthropod occurrence (100\%) in the diet of the species studied, reinforcing its importance as a food resource for small neotropical rodents (Talamoni et al. 2008; Lessa and Costa 2009; Pinotti et al. 2011; Sahley et al. 2015), especially in environments with a marked seasonality in resource availability, such as the Cerrado (see Pinheiro et al. 2002; Lessa and Costa 2009). Food availability may determine variations in the diet of some neotropical didelphids (Lessa and Geise 2014; Melo et al. 2019), imposing resource consumption according to their availability in the environment, which could reflect an opportunistic strategy. We recognize, however, that we did not measure food availability in our study site, which limited us to infer a possible opportunistic behavior regarding the diet of the studied rodent species. Nevertheless, based on our results and some studies that compare fruit and arthropod abundance between seasons in the Cerrado, we can hypothesize that the studied rodents may act as opportunistic foragers. In the Cerrado, fruits and arthropods are more abundant in the wet season (Pinheiro et al 2002; Mantovani and Martins 1988). On the other hand, Pinotti et al. (2011) did not observe arthropod consumption proportional to its availability (opportunistic behavior) in a study with some Sigmodontinae rodents in an Atlantic Forest area.

Our results indicate that four (C. subflavus, R. mastacalis, N. squamipes and N. lasiurus) of the six small rodent species studied may act as seed dispersers, that is, consuming fruits and dispersing small seeds ( $\leq 1 \mathrm{~mm}$ length) belonging to pioneer plants. According to Mariano et al. (2019), most seeds reaching the ground in the Cerrado are small ones $(\leq 1 \mathrm{~mm})$, exactly the type of seeds that could be dispersed by the rodent assemblage at our study site. When frugivorous dispersers accelerate the germinability of the seeds consumed (as in the case of Melastomataceae seeds in this study), ingested seeds take less time and have more successful germination than the ones that are not ingested (Verdú and Traveset 2004). For the study species, a probable benefit plant may derive from increased germination speed and germinability, which in pioneer plants may improve recruitment (Silveira et al. 2012). In this sense, seeds germinating earlier often have a fitness advantage compared to those that germinate later (Verdú and Traveset 2004. Moreover, reduced germination time may be advantageous in fire-prone habitats such as the Cerrado biome (Mariano et al. 2019). Efficient dispersal by animals may increase opportunities for colonization and provide a fire scape strategy for pioneer plants such as in melastomes from Cerrado (Silveira et al. 2012; Mariano et al. 2019).

Species belonging to the Melastomataceae and Rubiaceae in the Neotropics produce fruits that have been recorded as being consumed and dispersed by small pas- 
serines (Tabarelli and Peres 2002; Silveira et al. 2012), didelphid marsupials (Lessa et al. 2010; Cáceres and Lessa 2012; Lessa et al. 2013) and also small rodents (Horn et al. 2008; Vieira et al. 2003; Lessa and Costa 2009; Sahley et al. 2016). The Melastomatomes Clidemia spp. and Miconia spp. produce fleshy fruits rich in sugars and water, being consumed and dispersed primarily by birds (Silveira et al. 2012) and by didelphids marsupials (Lessa et al. 2013). In this study, Clidemia urceolata and Miconia holosericea seeds were consumed and dispersed by the rodents $R$. mastacalis, $N$. squamipes and $N$. lasiurus, with successful germination over $60 \%$, probably as a result of seed coat scarification (Samuels and Levey 2005; Silveira et al. 2012).

The Rubiaceae (Psychotria spp.) fruits are primarily consumed and dispersed by birds (particularly passerines) in the Neotropical region (Tabarelli and Peres 2002). In the same study area, Lessa et al. (2013) recorded the consumption of Rubiaceae fruits, in low proportions, by didelphid marsupials, with negative effects on the successful germination of the seeds ingested. We observed a similar pattern in the present study regarding consumption and dispersion of Psychotria spp. seeds by the rodent $C$. subflavus. Therefore, the simple passage of the seeds through the disperser digestive tract is not a pre-requisite that guarantees the increase in the germination success of the seeds ingested (Traveset 1998; Samuels and Levey 2005).

The rodent assemblage at our study site consumed a wide variety of food items, especially arthropods and fruits belonging to taxa that generally produce berries with small-seeded fruits. Our results also detected a low proportion of damaged seeds in the scats and confirmed that the seed germination of the ingested seeds was significantly higher than that of non-ingested seeds. Overall, small rodents are recognized specially as seed predators in the Neotropics (Carvajal and Adler 2008; David et al. 2015) but may be an overlooked source of endozoochoric seed dispersal in Neotropical savannas. In this sense, our results highlight the importance of these rodents' species to the dynamics of plant reproduction, especially for pioneer species belonging to the families Melastomataceae and Rubiaceae.

\section{Acknowledgements}

We are grateful to the Instituto Chico Mendes de Conservação da Biodiversidade (ICMBIO) for issuing the license to capture the animals (license no. 19790-1); and to the Instituto Estadual de Florestas de Minas Gerais (IEF/MG, Minas Gerais), for allowing the access to RPSP. Financial support was provided by the Fundação de Amparo a Pesquisa do Estado de Minas Gerais (FAPEMIG/MG) (grant no. APQ 01034/09).

\section{References}

Almeida LB, Galetti M (2007) Seed dispersal and spatial distribution of Attalea geraensis (Arecaceae) in two remnants of Cerrado in Southeastern Brazil. Acta Oecologica 32(2): 180-187. https://doi.org/10.1016/j.actao.2007.04.001 
Brewer SW, Rejmanék M (1999) Small rodents as significants dispersers of tree seeds in a Neotropical forest. Journal of Vegetation Science 10(2): 165-174. https://doi. org/10.2307/3237138

Briani DC, Junior PRG (2007) Fruit predation and fruit damage of Solanum lycocarpum (Solanaceae) by rodents in the Cerrado of central Brazil. Acta Oecologica 31(1): 8-12. https://doi.org/10.1016/j.actao.2006.01.008

Cáceres NC, Lessa LG (2012) O papel de marsupiais na dispersão de sementes. In: Cáceres NC (Ed.) Os marsupiais do Brasil: biologia, ecologia e conservação. Campo Grande, Ed. UFMS, 407-426.

Camargo NF, Ribeiro JF, Camargo AJA, Vieira EM (2014) Diet of the gracile mouse opossum Gracilinanus agilis (Didelphimorphia, Didelphidae) in a neotropical savanna: Intraespecific variation and resource selection. Acta Theriologica 59(1): 183-191. https:// doi.org/10.1007/s13364-013-0152-y

Cantor M, Ferreira LA, Silva WR, Setz EZF (2010) Potential seed dispersal by Didelphis albiventris (Marsupialia, Didelphidae) in highly disturbed environment. Biota Neotropica 10(2): 45-51. https://doi.org/10.1590/S1676-06032010000200004

Carvajal A, Adler GH (2008) Seed dispersal and predation by Proechimys semispinosus and Sciurus granatensis in central Panama. Journal of Tropical Ecology 24(05): 1-8. https:// doi.org/10.1017/S0266467408005270

David JP, Manakadan R, Ganesh T (2015) Frugivory and seed dispersal by birds and mammals in the coastal tropical dry evergreen forests of southern India: A review. Tropical Ecology 56: 41-55.

Dittel JW, Lambert TD, Adler GH (2015) Seed dispersal by rodents in a lowland forest in central Panama. Journal of Tropical Ecology 31(5): 403-412. https://doi.org/10.1017/ S0266467415000280

Emmons LH, Feer F (1997) Neotropical rainforest mammals: a field guide (2 ${ }^{\text {nd }}$ edn). The University of Chicago Press, Chicago, $396 \mathrm{pp}$.

Galetti M, Rodarte RR, Neves CL, Moreira M, Costa-Pereira R (2016) Trophic niche differentiation on Rodents and Marsupials revealed by stable isotopes. PLoS One 6: 1-15. https://doi.org/10.1371/journal.pone.0152494

Grenha V, Macedo MV, Pires AS, Monteiro RF (2010) The role of Cerradomys subflavus (Rodentia, Cricetidae) as seed predator and disperser of the palm Allagoptera arenaria. Mastozoología Neotropical 17: 61-68.

Haugaasen TJM, Peres CA, Gribel R, Wegge P (2010) Seed dispersal of the Brazil nut tree (Bertholletia excelsa) by scatter-hoarding rodents in a central Amazonian forest. Journal of Tropical Ecology 26(3): 251-262. https://doi.org/10.1017/ S0266467410000027

Horn GB, Kindel A, Hartz SM (2008) Akodon montensis (Thomas, 1913) (Muridae) as a disperser of endozoochoric seeds in a coastal swamp forest of southern Brazil. Mammalian Biology 73(4): 325-329. https://doi.org/10.1016/j.mambio.2007.10.008

Howe HF, Smallwood J (1982) Ecology of seed dispersal. Annual Review of Ecology and Systematics 13(1): 201-228. https://doi.org/10.1146/annurev.es.13.110182.001221 
Hurlbert SH (1984) Pseudoreplication and the design of ecological field experiments. Ecological Monographs 54(2): 187-211. https://doi.org/10.2307/1942661

Korschgen LJ (1987) Procedimentos para el análisis de los hábitos alimentares. In: Schemntitz SD (Ed.) Manual de técnicas de gestión de vida silvestre. The Wildlife Society, Washington, 119-134.

Lessa LG, Costa FN (2009) Food habits and seed dispersal by Thrichomys apereoides (Rodentia: Echimyidae) in a Brazilian cerrado reserve. Mastozoología Neotropical 16: 459-464.

Lessa LG, Geise L (2014) Food habits of Metachirus nudicaudatus (Didelphimorphia, Didelphidae) in a Brazilian Cerrado: Diet composition and dietary seasonality. Studies on Neotropical Fauna and Environment 49(2): 75-78. https://doi.org/10.1080/01650521.2014.924805

Lessa LG, Geise L, Costa FN (2013) Effects of gut passage on the germination of seeds ingested by didelphid marsupials in a Neotropical savanna. Acta Botanica Brasílica 27(3): 519-525. https://doi.org/10.1590/S0102-33062013000300009

Lessa LG, Paula CS (2014) Estrutura da comunidade de pequenos mamíferos em uma área de mata ciliar savânica no Parque Estadual do Rio Preto, Minas Gerais, Brasil. Neotropical Biology and Conservation 9(2): 98-104. https://doi.org/10.4013/nbc.2014.92.04

Magnusson WE, Sanaiotti T (1987) Dispersal of Miconia seeds by the rat Bolomys lasiurus. Journal of Tropical Ecology 3(3): 277-278. https://doi.org/10.1017/S0266467400002169

Mantovani W, Martins FR (1988) Variações fenológicas das espécies do cerrado da Reserva Biológica de Moji Guaçu, Estado de São Paulo. Revista Brasileira de Botanica. Brazilian Journal of Botany 11: 101-112.

Mariano V, Rebolo IF, Christianini AV (2019) Fire-sensitive species dominate seed rain after fire suppression: Implications for plant community diversity and wood encroachment in the Cerrado. Biotropica 51(1): 5-9. https://doi.org/10.1111/btp.12614

Melo GL, Santos AS, Sponchiado J, Cáceres NC, Lessa LG (2019) Feeding ecology of the marsupial Thylamys macrurus (Olfers, 1818) (Mammalia Didelphidae) in woodland patches of Cerrado, central-western, Brazil. Mammalia 82(1): 41-48. https://doi.org/10.1515/ mammalia-2017-0068

Neves SCN, Abreu PAA, Fraga LMS (2005) Fisiografia. In: Silva AC, Pedreira LCVSF, Abreu PAA (Eds) Serra do Espinhaço Meridional: Paisagens e ambientes. Belo Horizonte, O Lutador, 47-58.

Oliveira-Filho AT, Ratter JA (2002) Vegetation physiognomies and wood flora of the Cerrado biome. In: Oliveira PS, Marquis RJ (Eds) The Cerrados of Brazil: Ecology and natural history of a Neotropical savanna. Columbia University Press, New York. https://doi. org/10.7312/oliv12042-007

Paglia AP, Fonseca GAB, Rynalds AB, Herrmann G, Aguiar LMS, Chiarello AGY, Leite LR, Costa LP, Siciliano S, Kierulff MCM, Mendes SL, Tavares VC, Mittermeier RA, Patton JL (2012) Lista anotada dos mamíferos do Brasil, 2a edição. Occasional Papers in Conservation Biology. Arlington, Conservation International, $76 \mathrm{pp}$.

PattonJL, Pardiñas UFJ,D’Elia G (2015)Mammals ofSouth America, Volume2:Rodents. University of Chicago Press, Chicago. https://doi.org/10.7208/chicago/9780226169606.001.0001

Pinheiro F, Diniz IR, Coelho D, Bandeira MPS (2002) Seasonal pattens of insect abundance in the Brazil Cerrado. Austral Ecology 27(2): 132-136. https://doi.org/10.1046/j.14429993.2002.01165.x 
Pinotti BT, Naxara L, Pardini R (2011) Diet and food selection by small mammals in an old-growth Atlantic forest of south-eastern Brazil. Studies on Neotropical Fauna and Environment 46(1): 1-9. https://doi.org/10.1080/01650521.2010.535250

Polop F, Sepúlveda L, Sbriller AP, Polop J, Provensal MC (2014) Food habits of Oligoryzomys longicaudatus (Rodentia) in a steppe-forest transitional area of Argentinean Patagonia. Ecología Austral 24: 304-310.

Ranal MA, Santana DG (2006) How and why to measure the germination process? Revista Brasileira de Botanica. Brazilian Journal of Botany 29(1): 1-11. https://doi.org/10.1590/ S0100-84042006000100002

Sahley CT, Cervantes K, Pacheco V, Salas E, Paredes D, Alonso A (2015) Diet of a sigmodontine rodent assemblage in a Peruvian montane forest. Journal of Mammalogy 96(5): 1071-1080. https://doi.org/10.1093/jmammal/gyv112

Sahley CT, Cervantes K, Salas E, Pacheco V, Alonso A (2016) Primary seed dispersal by a sigmontine rodent assemblage in a Peruvian montane forest. Journal of Tropical Ecology 32(2): 125-134. https://doi.org/10.1017/S0266467416000043

Samuels IA, Levey DJ (2005) Effects of seed passage on seed germination: Do experiments answer the questions they ask? Functional Ecology 19(2): 365-368. https://doi. org/10.1111/j.1365-2435.2005.00973.x

Silveira FA, Ribeiro RC, Oliveira DM, Fernandes GW, Lemos-Filho JP (2012) Evolution of physiological dormancy multiple times in Melastomataceae from Neotropical montane vegetation. Seed Science Research 22(1): 37-44. https://doi.org/10.1017/ S0960258511000286

Tabarelli M, Peres CA (2002) Abiotic and vertebrate seed dispersal in the Brazilian Atlantic forest: Implications for forest regeneration. Biological Conservation 106(2): 165-176. https://doi.org/10.1016/S0006-3207(01)00243-9

Talamoni AS, Couto D, Cordeiro-Júnior DA, Diniz FM (2008) Diet of some species of Neotropical small mammals. Mammalian Biology 73(5): 337-341. https://doi.org/10.1016/j. mambio.2007.09.008

Traveset A (1998) Effects of seed passage through vertebrate frugivore's guts on seed germination: A review. Perspectives in Plant Ecology, Evolution and Systematics 1/2(2): 151-190. https://doi.org/10.1078/1433-8319-00057

Verdú MY, Traveset A (2004) Bridging meta-analysis and the comparative method: A test of seed size effect on germination after frugivores gut passage. Oecology 138(3): 414-418. https://doi.org/10.1007/s00442-003-1448-4

Vieira EM, Pizo MA, Izar P (2003) Fruit and seed exploitation by small rodents of the Brazilian Atlantic Forest. Mammalia 67(4): 533-539. https://doi.org/10.1515/mamm2003-0407

Vieira EM, Paise G, Machado HD (2006) Feeding of small rodents on seeds and fruits: A comparative analysis of three species of rodents of the Araucaria forest, southern Brazil. Acta Theriologica 51(3): 311-318. https://doi.org/10.1007/BF03192683

Zar JH (2010) Bioestatistical Analysis ( $5^{\text {th }}$ edn). Prentice Hall, Upper Saddle River, New Jersey, $663 \mathrm{pp}$. 